\title{
The adaptation of the students' beliefs about peer feedback scale into Turkish: a validity and reliability study
}

\author{
Begüm İhtiyaryer, Fatih Sultan Mehmet Vakıf University, Turkey, begumihtiyaryer@gmail.com, ORCID: \\ 0000-0002-6549-5951 \\ Bülent Alcı, Ylldız Technical University, Turkey, bulent alci@hotmail.com, ORCID: 0000-0002-4720-3855
}

\begin{abstract}
The purpose of this research is to adapt the Students' Beliefs about Peer-feedback Scale developed by Huisman (2018) into Turkish and study validity and reliability in the adapted scale. After the linguistic equivalence study, the form was filled by 100 university students who study at English preparatory school. The EFA showed that the total explained variance was $67 \%$ and the items in the scale were loaded under 3 factors. The CFA confirmed the factors determined in EFA. The reliability study indicated that the Cronbach alpha coefficient was .80.According to the item analysis, $t$ test results between $27 \%$ upper and lower groups were statistically significant. Finally, the two halves of the scale were found to be correlated at .59 level. As a result, this study showed that 'The Students' Beliefs about Peer Feedback scale' was a valid and reliable scale to measure students' beliefs on peer-feedback in the Turkish context.
\end{abstract}

Keywords: Peer-feedback, Students' beliefs, Feedback

Received: 10.05 .2020

Accepted: 17.08 .2020

Published: 01.12.2020

\section{INTRODUCTION}

Feedback is the most basic part of both the teaching and learning processes (Clynes \& Raftery, 2008). Learners who get proper feedback on their product can be aware of their mistakes and therefore improve themselves. From the point of instructors or whoever teaches something, giving feedback makes the process more concrete and easier. For this reason, ignoring feedback affects the learning process because feedback is an important approach that allows students to be responsible for their own learning as independent learners, to evaluate themselves and to make necessary arrangements (Ferguson, 2011; as cited in Al-Bashir et al., 2016). A student who receives effective feedback will look at his or her learning process from the outside, will be able to direct the learning process, recognize and correct his or her mistakes. In line with this information, Clynes and Raftery (2008) express that feedback increases students' selfconfidence.

It is not always the teachers who provide feedback in learning atmosphere. In terms of the person who evaluates the product that result from learning, feedback is given by teachers and peers (Coşkun \& Tamer, 2015). With the teacher feedback, the student receives written or oral feedback from the teacher on his study while with peer feedback he receives written or verbal feedback from a peer who is in the same learning process like him. Depending on what is planned, peers can rate each other's products, as well as interpret and criticize them, that is, provide oral and written evaluation for each other (Hamzadayı \& Çetinkaya, 2011). Tamer and Coşkun (2015) state that with peer feedback, the student who gives feedback to someone else's product has a good command of what should be in a good product and also is aware of enriching a product from another point of view. So, one of the benefits of peer feedback is that students get more information about the topic they will give feedback on and therefore provide better feedback in this way.

"Peer assessment" emerged as a teaching activity in line with Vygotsky's social constructivism theory (Hamzadayı \& Çetinkaya, 2011). An individual can reach the potential beating limit by getting support from his social environment, which was described as the zone of proximal development by Vygostky. In accordance with this definition, individuals can improve themselves with the help of their social environments with peer feedback. Topping 
(2009) states that peer assessment is not just part of the school and therefore enhances transferable skills for life because we can be asked to assess each other's work in everyday life.

In addition to the benefits of peer feedback, such as reducing student anxiety, increasing self-confidence, and saving time for the teacher, there are also studies showing limitations such as mistakes not being detected correctly by peers, not scoring fairly, and giving inappropriate feedback (Tamer \& Coşkun, 2015). If the limitations are overcome, students may make use of peer feedback better. Here, teaching how to give peer feedback is the key point in lessons where students are supposed to provide feedback for each other.

When the literature is examined, many researches on peer feedback can be seen. Efe (2014) investigated the perceptions of students who learned English on peer feedback within his master's thesis, and while doing this, he adapted a questionnaire containing 9 open-ended questions. Similarly, Kaynak (2017) used a semi-structured interview to determine "the effect of peer feedback on students' writing anxieties and their attitudes towards peer feedback" in his master's thesis. Efe (2014) found that students had positive attitudes about peer-feedback in their writing lessons and Kaynak (2017) put forward that peer-feedback reduced writing anxiety. Apart from these, Huisman (2018) worked on a scale to reveal the beliefs of higher education students in peer feedback as a teaching method within the scope of his PhD thesis titled "Peer feedback on academic writing: effects on performance and the role of task-design". The Students' Beliefs About Peer-Feedback Scale is important since it has been designed duly for university students and is a relatively recent study.

Huisman (2018) reveals the need for such a scale by stating that beliefs affect the behavior. The scale he prepared consists of 4 sections and 10 items in total. In the scale of students' beliefs about peer feedback, the first part is "Valuation of peer feedback as an instructional method", the second part is "Valuation of peer feedback as an important skill", third part is "Confidence in own peer feedback quality" and finally the fourth part is "Confidence in the quality of peer feedback received". A five point likert type was used for the scale. Unlike the semi-structured interview and open-ended questions existing in the literature, a new scale has been added to the literature within the scope of that new study on the subject.

The purpose of this study is to study validity and reliability of the Turkish form of Huisman's (2018) Students' Beliefs about the Peer Feedback on the sample of university students, which presents a recent study in the literature. The reason behind this study is to investigate university students' beliefs about peer-feedback in Turkish universities and therefore to put forward ideas on peer-feedback technique used in lessons. There have been some studies on peer-feedback but students' attitudes towards it should also be evaluated. It is obvious that peer-feedback is valuable in both learning and teaching processes. However, to what extent students perceive this value as a learning component and whether they believe in the power of peer-feedback are the motivations to maintain this research? The adaptation of this scale makes it possible to understand Turkish students' beliefs on the topic, which may end in some changes in curriculum about peer-feedback.

\section{METHOD}

\section{Sample}

The sample group consists of 100 students studying in a private university in İstanbul in the 2019-2020 academic year. The frequency data regarding the participants' the demographic information are presented in Table 1.

According to Table $1,58 \%$ of the participants are female and $42 \%$ are male. It is also seen that $77 \%$ of the participants are aged between 17 and 20;22\% are between 21 and 24 and there is only 1 participant who is above 25 . 
Table 1. Demographic Information

\begin{tabular}{clll}
\hline & & Frequency & Percentage \\
\hline \multirow{3}{*}{ Gender } & Female & 58 & 58,0 \\
& Male & 42 & 42,0 \\
\hline \multirow{2}{*}{ Age } & $17-20$ & 77 & 77,0 \\
& $21-24$ & 22 & 22,0 \\
& $25+$ & 1 & 1,0 \\
\hline Total & & 100 & 100,0 \\
\hline
\end{tabular}

\section{Data Collection Tool}

\section{Students' Beliefs about the Peer Feedback Scale}

Students' Beliefs about Peer-Feedback Scale was developed by Huisman (2018) in order to reach the information regarding how students consider peer feedback. It consists of 4 subcategories and 10 items in total, which all indicate positive sentence structures. The scale was administered in paper-pencil format and responses on all items were provided on a 5-point Likert scale. Therefore, the lowest number that a student can get from the scale is 10 while the highest number is 50. The Exploratory Factor Analysis of the scale was completed with 220 students and the Confirmatory Factor Analysis was completed with 121 university students. As a result of EFA, it is seen that individual items values range from .57 to .87 . And inter-item correlations appear adequately large as Bartlett's test $\chi 2(45)=630.97, p<.001$. The other values Huisman obtained are TLI $=.91, \mathrm{CFI}=.94$, RMSEA $=.089[.05, .12]$, SRMR $=.06$. As a result of CFA, Huisman (2018) founds that the scale confirms the structure. For the reliability, the Cronbach alpha coefficient of the four parts within the questionnaire was found to range from .67 to .82 (Huisman, 2018).

\section{Implementation}

The first step that was taken to adapt the scale was to get required permission from the researcher, who developed Students' Beliefs about the Peer Feedback Scale, Bartt Huisman. After the permission, the English form of the scale was firstly translated into Turkish by the researcher herself and was proofread by 3 instructors of English who work at universities' English preparatory schools. With the feedback received, necessary editing was made on the scale. The Turkish form of the scale was then sent to a native speaker of English who is proficient in Turkish, too. In line with the feedback received, the last version of the scale was prepared. At the final stage, the backward translation was performed on the scale from Turkish to English this time.

To test the linguistic equivalence, the Turkish and English forms of the scale were implemented to 38 students who have completed B2 level of English in the same university. The participants firstly received the Turkish form and received the English form of the scale three weeks later.

The Turkish form was implemented to 100 students who study in the same university in the 2019-2020 academic year spring term. The scales were done in paper-pencil format in class and it took 10 minutes. For the validity study of the scale, structural validity was examined. The reliability study was examined with Cronbach alpha coefficient. In addition, the mean scores belonging to lower $27 \%$ and upper $27 \%$ groups divided according to the total scores of the test were tested with independent t-test. Finally, split half reliability test was analyzed through Spearman Brown. 


\section{RESULTS}

\section{Linguistic Equivalence}

The data coming from both Turkish and English forms were analyzed through SPSS 22. The relationship between the total points gathered from the Turkish and English forms of the scales was examined through Pearson Moment Correlation. The same process was implemented for the subscales of both forms.

Table 2. Correlation coefficient between Turkish and English forms

\begin{tabular}{|c|c|c|}
\hline Subscales & Language & Value \\
\hline $\begin{array}{l}\text { Valuation of peer feedback as an } \\
\text { instructional method }\end{array}$ & $\begin{array}{l}\text { Turkish } \\
\text { English }\end{array}$ & $.52 * *$ \\
\hline $\begin{array}{l}\text { Valuation of peer feedback as an } \\
\text { important skill }\end{array}$ & $\begin{array}{l}\text { Turkish } \\
\text { English }\end{array}$ & $.71^{* *}$ \\
\hline $\begin{array}{l}\text { Confidence in own peer feedback } \\
\text { quality }\end{array}$ & $\begin{array}{l}\text { Turkish } \\
\text { English }\end{array}$ & $.95^{* *}$ \\
\hline $\begin{array}{l}\text { Confidence in the quality of peer } \\
\text { feedback received }\end{array}$ & $\begin{array}{l}\text { Turkish } \\
\text { English }\end{array}$ & $.53^{* *}$ \\
\hline Total & $\begin{array}{l}\text { Turkish } \\
\text { English }\end{array}$ & $.98^{* *}$ \\
\hline
\end{tabular}

${ }^{* *} p<.01$

Table 2 shows that the correlation coefficient of the total points between two scales was found to be .98 , which is statistically significant $(\mathrm{p}<.01)$. In addition, the correlation of the total points of each subscale of both Turkish and English forms were examined and it was found that the correlation coefficient between Turkish and English subscales 1 was .52, the correlation between the subscales 2 was .71, the correlation between the subscales 3 was .95 and the correlation between the subscales 4 was .53 , which were statistically significant $(p<.01)$. Therefore, it can be said that there is a correlation between the original and the translated forms and it shows that the translated one meets the requirement for the linguistic equivalence. After the correlation study, independent t-test was applied to compare the Turkish and English forms. The test results indicate that there is not a significant difference between the two forms. Table 3 represents the independent $t$-test results.

Table 3. Independent t-test values between Turkish and English forms

\begin{tabular}{lllc}
\hline Subscales & Language & Mean & Independent t-test \\
\hline $\begin{array}{llll}\text { Valuation of peer feedback as an instructional } \\
\text { method }\end{array}$ & Turkish & 10.16 & .206 \\
& English & 10.76 & \\
Valuation of peer feedback as an important skill & Turkish & 12.21 & .210 \\
& English & 11.53 & \\
Confidence in own peer feedback quality & Turkish & 7.21 & .566 \\
& English & 7.42 & .481 \\
Confidence in the quality of peer feedback received & Turkish & 7.03 & \\
& English & 6.74 & .90 \\
Total & Turkish & 36.61 & \\
& English & 36.45 & \\
\hline
\end{tabular}




\section{Validity Study}

Factor analysis was implemented to examine the construct validity of the. The purpose of doing a factor analysis is explaining the estimates with less number of factors by bringing together the items that deal with the similar structure (Hazar \& Hazar, 2019). Two types of factor analysis are present, which are EFA and CFA.

\section{Exploratory Factor Analysis (EFA)}

Doing an exploratory factor analysis (EFA) identifies the number of structures and the underlying factor loads within a scale (Suhr, 2006). In other words, Exploratory Factor Analysis (EFA) is done to find a factor based on the relationships between variables (Hazar \& Hazar, 2019). Büyüköztürk (2002) states that EFA can be studied with Kaiser Meyer Olkin (KMO) coefficient together with Barlett Sphericity Test. Table 4 below shows the KMO coefficient and Barlett Sphericity test results for the scale.

Table 4. KMO and bartlett's test results

\begin{tabular}{llr}
\hline Kaiser-Meyer-Olkin & &, 776 \\
Bartlett's Test of Sphericity & Approx. Chi-Square & 367,558 \\
& df & 45 \\
& Sig. &, $000^{*}$ \\
\hline
\end{tabular}

${ }^{*} \mathrm{p}<0.001$

The KMO coefficient should be at least .60 and above and the Barlett test should also be significant ( $\mathrm{p}<.05$ ) (Tabachnick \& Fidell, 2013, as cited in Katrancı \& Temel, 2018).Table 4 shows that KMO coefficient for the scale is .77 which is above .60 and Bartlett Test is significant at .001 level. This information shows that the data are appropriate for EFA and the sample size is sufficient. In order to obtain the factor structure of the 10-item scale, the exploratory factor analysis values gathered from the data obtained from 100 participants are given in Table 5.

Table 5. Common factor variance values of the items

\begin{tabular}{rr}
\hline Common Factor Variance & \\
\hline 1 &, 757 \\
2 &, 720 \\
3 &, 687 \\
4 &, 745 \\
5 &, 760 \\
6 &, 774 \\
7 &, 568 \\
8 &, 550 \\
9 &, 642 \\
10 &, 522 \\
\hline
\end{tabular}

Table 5 shows the common factor variance values of the scale items. These values depend on the load values of the items in each factor. A factor loading value of .45 or higher is a good indicator (Telef, 2013). According to the table, it is clear that the values range from .52 to .77 .

In order to decide how many significant factors the scale items measure, it is suggested to look at the initial eigenvalue and the explained variance rates. Table 6 contains the information about the eigenvalue and the explained variance rates. 
Table 6. Initial eigenvalue and variance rates of the scale

\begin{tabular}{lcccccc}
\hline Item No & \multicolumn{3}{c}{ Initial Eigenvalues } & \multicolumn{3}{c}{ Extraction Sums of Loadings } \\
& Total & Variance & Cumulative & Total & Variance & Cumulative \\
& & & & & & \\
\hline $\mathbf{1}$ & 4,011 & 40,108 & 40,108 & 4,011 & 40,108 & 40,108 \\
$\mathbf{2}$ & & & & & \\
& 1,486 & 14,864 & 54,972 & 1,486 & 14,864 & 54,972 \\
$\mathbf{3}$ & & & & & \\
& 1,227 & 12,271 & 67,243 & 1,227 & 12,271 & 67,243 \\
$\mathbf{4}$ & & & & & \\
$\mathbf{5}$ &, 774 & 7,744 & 74,987 & & \\
$\mathbf{6}$ &, 640 & 6,400 & 81,387 & & \\
$\mathbf{7}$ &, 531 & 5,306 & 86,693 & & \\
$\mathbf{8}$ &, 437 & 4,373 & 91,066 & & \\
$\mathbf{9}$ &, 364 & 3,640 & 94,707 & & \\
$\mathbf{1 0}$ &, 313 & 3,131 & 97,837 & & & \\
\hline
\end{tabular}

When Table 6 is examined, it is understood that the scale has a structure of 3 factors with $1 \%$ eigenvalue that explains $67.24 \%$ of the total variance.

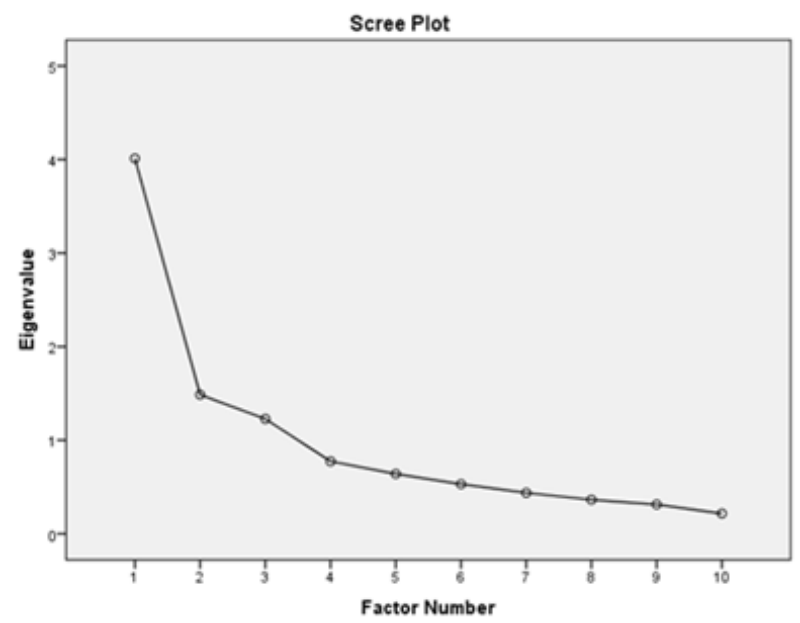

FIGURE 1. Factors loaded in the scale

Figure 1 indicates the three factors loaded in the scale. As can be seen, after the third factor the eigenvalues are below 1.

As stated before, Huisman (2018) developed the original scale with 4 subcategories. As a result of EFA carried out, he reached the conclusion that if the scale has 4 categories the total explained variance was higher than that of the scale with 3 categories. Therefore he accepted the scale with 4 categories. Similarly in this research, it was found out that the items were loaded on 3 factors. Although it is seen that there are 4 factors in the original form, this shows only 3 factors that are loaded, which are 'Valuation of peer feedback as an instructional method, Valuation of peer feedback as an important skill and Confidence in peer feedback'. Here it is obvious that the values attached to given and received peer-feedback were combined under one factor. The fact that the original scale and the adapted scale have different factor numbers shows the difference between the cultures in which the original and the adapted scales were implemented (Erkuş, 2007).

The detailed information regarding the factor loads is presented in Table 7. 
Table 7. Items of the scale and their factor loadings as a result of EFA

\begin{tabular}{|c|c|c|c|}
\hline \multirow[t]{2}{*}{ Factors } & \multicolumn{3}{|c|}{ Factor Loadings } \\
\hline & 1 & 2 & 3 \\
\hline \multicolumn{4}{|l|}{ Factor 1: Confidence in peer feedback } \\
\hline $\begin{array}{l}\text { 9. In general, I am confident that the peer feedback I receive from } \\
\text { other students is of good quality. }\end{array}$ & .79 & & \\
\hline $\begin{array}{l}\text { 7. In general, I am confident that the peer feedback I provide to } \\
\text { other students is of good quality. }\end{array}$ & .70 & & \\
\hline $\begin{array}{l}\text { 10. In general, I am confident that the peer feedback I receive from } \\
\text { other students helps me to improve my work. }\end{array}$ & .67 & & \\
\hline $\begin{array}{l}\text { 8. In general, I am confident that the peer feedback I provide to } \\
\text { other students helps them to improve their work. }\end{array}$ & .63 & & \\
\hline \multicolumn{4}{|l|}{ Factor 2: Valuation of peer feedback as an important skill } \\
\hline $\begin{array}{l}\text { 4. Being capable of giving constructive peer feedback is an } \\
\text { important skill. }\end{array}$ & & .84 & \\
\hline $\begin{array}{l}\text { 6. Being capable of improving one's work based on received peer } \\
\text { feedback is an important skill. }\end{array}$ & & .83 & \\
\hline $\begin{array}{l}\text { 5. Being capable of dealing with critical peer feedback is an } \\
\text { important skill. }\end{array}$ & & .83 & \\
\hline \multicolumn{4}{|l|}{$\begin{array}{l}\text { Factor 3: Valuation of peer feedback as an instructional } \\
\text { method }\end{array}$} \\
\hline 3. Feedback should only be provided by the teaching staff. & & & .77 \\
\hline $\begin{array}{l}\text { 1. Involving students in feedback through the use of peer feedback } \\
\text { is meaningful }\end{array}$ & & & .74 \\
\hline 2. Peer feedback within [course] is useful. & & & .73 \\
\hline
\end{tabular}

When Table 7 is studied, it is concluded that the factor loading values in Factor 3 range from .73 to .77; the ones in Factor 2 range from .83 to .84 and the ones in Factor 1 range from .63 to .79 .

\section{Confirmatory Factor Analysis (CFA)}

Doing a confirmatory factor analysis is a method generally applied after classical factor analysis studies (Ylldız \& Bulut, 2016). The factors determined through EFA are confirmed via CFA. In order to consider the CFA results as valid, the goodness-of-fit indices should be sufficient. These sufficiency values and the CFA results are presented in Table 8. CFA analysis was made in Lisrel 8.8 program.

Table 8. CFA goodness of fit acceptable values and results

\begin{tabular}{|c|c|c|c|c|}
\hline & $\begin{array}{l}\text { Perfect } \\
\text { Indices }\end{array}$ & $\begin{array}{l}\text { Acceptable } \quad \text { Fit } \\
\text { Indices }\end{array}$ & $\begin{array}{l}\text { The Scale } \\
\text { Indices }\end{array}$ & Fit \\
\hline$\chi^{2 / d f}$ & $0 \leq \chi 2 / \mathrm{df} \leq 2$ & $2 \leq \chi 2 / d f \leq 3$ & 1.26 & \\
\hline RMSEA & $0 \leq \mathrm{RMSEA} \leq 0,05$ & $\begin{array}{l}0,05 \leq \text { RMSEA } \\
\leq 0,10\end{array}$ & .05 & \\
\hline GFI & $0,85 \leq \mathrm{GFI} \leq 1$ & $0,90 \leq \mathrm{GFI} \leq 0,95$ & .92 & \\
\hline AGFI & $0,90 \leq \mathrm{AGFI} \leq 1$ & $0,85 \leq \mathrm{AGFI} \leq 0,90$ & .87 & \\
\hline CFI & $0,95 \leq \mathrm{CFI} \leq 1$ & $0,90 \leq \mathrm{CFI} \leq 0,95$ & .97 & \\
\hline IFI & $0,95 \leq \mathrm{IFI} \leq 1$ & $0,90 \leq \mathrm{IFI} \leq 0,95$ & .97 & \\
\hline PGFI & $0.95 \leq \mathrm{PGFI} \leq 1.00$ & $0.50 \leq \mathrm{PGFI} \leq 0.95$ & .54 & \\
\hline PNFI & $0.95 \leq \mathrm{PNFI} \leq 1.00$ & $0.50 \leq \mathrm{PNFI} \leq 0.95$ & .65 & \\
\hline
\end{tabular}

Kline, (2011) as cited in Ylldız \& Bulut (2016)

The results of CFA be seen in Table 8. According to these results, the fit values of the scale are as follows; $x^{2} /$ sd (40.56/32): 1.26, RMSEA: .05, GFI=.92, AGFI=.87, CFI=.97, IFI: .97, PGFI: .54 and PNFI: .65. It is seen that the data are between perfect and acceptable values referred by Kline (2011), which therefore confirms the factors in the scale. While $\chi 2$, RMSEA, 
CFI and IFI values show the perfect fit indices; GFI, AGFI, PGFI and PNFI values show acceptable fit indices. The diagram is given in Figure 2.



FIGURE 2. Standardized values of the scale

\section{Reliability Study}

Item 3 was determined to be negative and therefore recoded into same variable. After recoding item 3 , it was seen that the Cronbach alpha score of the whole scale was higher and the result is presented in Table 9 below.

Table 9. Cronbach alpha coefficient of the scale

\begin{tabular}{lll}
\hline & Cronbach Alpha $\alpha$ & Number of Items \\
\hline Scale & .80 & 10 \\
\hline
\end{tabular}

The commonly accepted approach for Cronbach alpha is that if $\alpha \geq 0.6$, it is acceptable (Kilıç, 2016). The result of the anaylsis shows that the scale's reliability score is .80, which is $\geq$ 0.6 .

In addition to the total score, the reliability scores for each factor were analyzed and presented in Table 10.

Table 10. Reliability scores for the factors

\begin{tabular}{lll}
\hline Factor & Cronbach Alpha $\boldsymbol{\alpha}$ & Number of Items \\
\hline Factor 1 & .74 & 4 \\
Factor 2 & .83 & 3 \\
Factor 3 & .67 & 3 \\
\hline
\end{tabular}

Having a look at the Table 10, it is obvious that Cronbach Alpha coefficients are between .67 and .83 for the factors within the scale. Therefore the reliability scores of the factors within the scale are acceptable.

The correlation between the factor loads was also examined and the findings are presented in Table 11. 
Table 11. Correlation coefficient among the factors

\begin{tabular}{llll}
\hline & Factor 1 & Factor 2 & Factor 3 \\
\hline Factor 1 & 1 & $.280^{* *}$ & $.317^{* *}$ \\
Factor 2 & $.280^{* *}$ & 1 & $.488^{* *}$ \\
Factor 3 & $.317^{* *}$ & $.488^{* *}$ & 1 \\
\hline
\end{tabular}

$\mathrm{p}<.01^{* *}$

Table 11 shows that the correlation coefficient among the factors is statistically significant at .01 level. The correlation coefficient can be defined as high if between 0.70-1.00; moderate if between 0.70-0.30, and low between 0.30-0.00 (Büyüköztürk, 2002). As a result of the analysis, the correlation values of the factors range from .28 to .48 , which indicates that the factors can be said to have a moderate and low correlation with each other.

\section{Item Analysis}

The item analysis of the scale was examined by looking at the item-total correlation coefficients and the difference between $27 \%$ upper and $27 \%$ lower groups. Item-total correlation states the relationship between the individual scores gathered from the individual test items and the total score gathered from the test; positive item total correlations show that the item has similar features; therefore the internal consistency of the test is high (Telef, 2013). Items with .30 and above correlation are accepted to differentiate among individuals (Büyüköztürk, 2002). The item-total correlation coefficient and the t-test result for the difference between the 27\% upper and 27\% lower groups were presented in Table 12.

Table 12. Item analysis results for the scale

\begin{tabular}{ccc}
\hline Item No & Item-Total Correlation & $\begin{array}{c}\text { t-test } \\
\text { (27\% upper - 27\% lower) }\end{array}$ \\
\hline $\mathbf{1}$ & .73 & 10.0 \\
$\mathbf{2}$ & .69 & 7.4 \\
$\mathbf{3}$ & .24 & 2.7 \\
$\mathbf{4}$ & .63 & 4.7 \\
$\mathbf{5}$ & .65 & 4.8 \\
$\mathbf{6}$ & .69 & 5.3 \\
$\mathbf{7}$ & .59 & 5.6 \\
$\mathbf{8}$ & .68 & 7.3 \\
$\mathbf{9}$ & .54 & 4.0 \\
$\mathbf{1 0}$ & .60 & 5.1 \\
\hline$* \mathrm{p}<.001$ & &
\end{tabular}

When Table 12 is studied, it is concluded that the lowest correlation belongs to the item 3 in the scale. If the correlation of an item with the total score is low, it is said that the item tests a different fact from the other items in the scale and this reduces the reliability of the test (Özgüven, 1994, as cited in Yavuz, 2006). Therefore it can be said that this item does not differentiate the participants since it is below .30. Apart from item 3 , the item-total correlation coefficient ranges from .54 to 73 . In addition, the t-test values except for the item 3 were found 
to be statistically significant. The further results are obtained from the two groups of the participants (27\% upper \& $27 \%$ lower groups), the more distinctive the items are evaluated (Yavuz, 2006). All these suggest that the item number 3 does not discriminate the participants. Therefore it should be eliminated from the scale in the Turkish context.

\section{Split Half Reliability Test}

The reliability coefficient obtained after grouping the scale into two is called the split half reliability. Tavşancll (2006) states that split half reliability test is the most used method to see the reliability of the scale and if the scale has subcategories, each subcategory can be accepted as a whole scale and the test can be applied for the subcategories. The scale was divided into two parts according to odd and even numbers of the items. Then, two data sets of total points were analyzed through Spearman Brown test for the factors and the total point, which can be seen in Table 13.

Table 13. Spearman brown split half test reliability results

\begin{tabular}{ll}
\hline Factor & Split Half Test Correlation \\
\hline Factor 1 & $.569^{* *}$ \\
Factor 2 & $.693^{* *}$ \\
Factor 3 & $.293^{* *}$ \\
Total & $.591^{* *}$ \\
\hline $\mathrm{p}<.01$ &
\end{tabular}

Table 13 highlights that the relationship between the halves of the scale is significant, which is another proof of the reliability of the scale.

\section{DISCUSSION and CONCLUSIONS}

This research aims to adapt 'Students' Beliefs about Peer-Feedback Scale' developed by Bartt Huisman (2018) into Turkish and study the reliability and validity of the adapted scale. The first step was to examine the linguistic equivalence of the translated scale. It was observed that the relationship was statistically significant between the English and Turkish forms of the scale, which can be uttered as sufficient for the linguistic equivalence. As a result of the EFA, it was seen that the scale has 3 factors unlike the original form which had 4 factors. Since psychological parameters depend on the culture in which the research is carried out, it is normal to see this kind of differences. Erkuss (2007) states that the factor structure in the adapted culture should be taken into account not the one in the original scale. This shows that the factors in the original scale, which are 'Confidence in quality of received peer feedback' and 'Confidence in own peer feedback quality', are combined under one factor which is 'Confidence in quality of peer feedback' since the verbs to give and to receive do not make a huge difference in terms of the general confidence about peer feedback in the Turkish context. This shows that the items that are similar to each other are grouped together for the sample of the research (Sarıgül, 2014).

The Cronbach alpha coefficient of the scale was found to be suitable. The reliability coefficient calculated for a psychological test to be .70 and above looks sufficient for the test scores to be reliable (Büyüköztürk, 2002). With the item analysis, it was concluded that the item-total correlation coefficient and the t-test values except for the item 3 were found to be statistically significant. As a conclusion, item 3 should be eliminated from the scale since it has a low item-total correlation and a low t-test score, which indicates that the item does not discriminate the participants. Finally, the last step to study the reliability was the Split Half Test 
way. After dividing the scale into two groups, the correlation between these two parts were analyzed and it was found to be significant, which shows that the scale is reliable.

After the validity and reliability studies, it can be said that 'The Students' Beliefs about Peer Feedback Scale' is suitable for use in the field of feedback studies in the Turkish context. Nevertheless, the scale can be tested on its validity and reliability with larger samples in the future. The adapted scale can be applied for university students on peer-feedback in Turkey and it can provide the stakeholders with the data to understand students' beliefs on the topic in order to take actions within the curriculum followed.

\section{REFERENCES}

Al-Bashir, M., Kabir, R. \& Rahman, I. (2016). The Value and Effectiveness of Feedback in Improving Students' Learning and Professionalizing Teaching in Higher Education. Journal of Education and Practice, 7 (16), 38-41.

Büyüköztürk, Ş. (2002). Faktör Analizi: Temel Kavramlar Ve Ölçek Gelistirmede Kullanımı. Kuram ve Uygulamada Eğitim Yönetimi, 32, 470-483.

Clynes, M. P. \& Raftery, S. E. C. (2008). Feedback: an essential element of student learning in clinical practice, Nordic Nurse Education in Practice, 8(6), 405-411.

Coskun, E. \& Tamer, M. (2015). Yazma Eğitiminde Geri Bildirim Türleri ve Kullanımı. Mustafa Kemal Üniversitesi Sosyal Bilimler Enstitüsü Dergisi, 12(32), 337 - 372.

Efe, B. (2014). The Effect of Peer Feedback on Students' Overall Writingg Performance and Their Attitudes toward Peer Feedback. Unpublished MA Dissertation, Çağ Üniversitesi Sosyal Bilimler Enstitüsü, Mersin.

Erkuş, A. (2007). Ölçek Geliştirme ve Uyarlama Çalışmalarında Karşılaşılan Sorunlar. Türk Psikoloji Bülten, 40(17). 17-25.

Hamzadayı, E. ve Çetinkaya G. (2011). Yazılı Anlatımı Düzenlemede Akran Dönütleri: Dönüt Türleri, Öğrenci Algıları, Abant İzzet Baysal Üniversitesi Ĕ̈itim Fakültesi Dergisi, 11(1), 147-165.

Hazar, E. \& Hazar, Z. (2019). Üniversite Öğrencileri İçin Dijital Oyun Bağımlılığı Ölçeği Uyarlama Çalışması. Spor Bilimleri Araştırmaları Dergisi, 4(2), 309-322.

Huissman, B.A. (2018). Peer feedback on academic writing: effects on performance and the role of taskdesign. Unpublished PHD Dissertation, Leiden University, Leiden.

Katrancı, M. \& Temel, S. (2018). İlkokul Öğrencilerine Yönelik Yazma Kaygisi Ölçeği: Geçerlik Ve Güvenirlik Çalișmasi. Journal of Social and Humanities Sciences Research, 5(24), 1544-1555.

Kaynak, M. (2017). Impact of peer feedback on EFL learners's foreign language writing anxiety and their ideas about peer feedback. Unpublished MA Dissertation, Anadolu University, Institute of Educational Sciences, English Language Teaching Program, Eskişehir.

Kilıç, S. (2016). Cronbach's alpha reliability coefficient. Journal of Mood Disorders, 6(1), 47-48.

Sarıgül, R. H. (2014). Türkçeye Uyarlanmış Davranış Etkinleștirme Ölçeği'nin Geçerlik Ve Güvenirlik Çalışması. Unpublished MA Dissertation, Haliç Üniversitesi, Institute of Social Sciences, Psychology Department, İstanbul.

Suhr, D. D. (2006). Exploratory or confirmatory factor analysis? (1-17). In.Cary: SAS Institute. Tabachnick Tavşancıl, E. (2006). Tutumların ölçülmesi ve spss ile veri analizi. Ankara: Nobel Yayın Dağıtım.

Telef, B. B. (2013). Psikolojik İyi Oluş Ölçeği: Türkçeye Uyarlama, Geçerlik ve Güvenirlik Çalışması. Hacettepe Üniversitesi Eğitim Fakültesi Dergisi, 28(3), 374-384.

Topping, K. J. (2009). Peer Assessment, Theory Into Practice, 48(1), 20-27.

Yavuz, F. (2006). Okul Motivasyonunu Değerlendirme Ölçeği Yapilandirilmasi Ve Güvenirliği. Unpublished MA Dissertation, Marmara University, Institute of Educational Sciences, Department of Guidance and Psychological Counseling, İstanbul.

Yıldız, M. \& Bulut, A. (2016). Okur Benlik Algisi Ölçeği: Geçerlik Ve Güvenirlik Çalişmasi. International Journal of Eurasia Social Sciences, 7(22), 311-326. 